\title{
[Regular Paper] \\ Conversion of Ethanol into Propylene over TON Type Zeolite
}

\author{
Nao Tsunoj, Yoshiyasu Furumoto, Yusuke IDE, Masahiro SADAKAnE, and Tsuneji SANO* \\ Dept. of Applied Chemistry, Graduate School of Engineering, Hiroshima University, \\ 1-4-1 Kagamiyama, Higashi-Hiroshima, Hiroshima 739-8527, JAPAN
}

(Received April 29, 2012)

\begin{abstract}
TON type zeolites with different $\mathrm{SiO}_{2} / \mathrm{Al}_{2} \mathrm{O}_{3}$ ratios $(57,81,112$, and 140) were synthesized using 1,6-diaminohexane, $n$-butyl alcohol, and 1-ethylpyridinium bromide as structure-directing agents, and the catalytic performance of protonated forms for conversion of ethanol into light olefins such as ethylene, propylene, and butenes was investigated. Although the yields of light olefins were dependent on the $\mathrm{SiO}_{2} / \mathrm{Al}_{2} \mathrm{O}_{3}$ ratios of the HTON type zeolites and the reaction conditions such as temperature and contact time, the relatively high propylene yield of $c a$. $25 \mathrm{C}-\%$ was obtained. HTONs with higher $\mathrm{SiO}_{2} / \mathrm{Al}_{2} \mathrm{O}_{3}$ ratios exhibited longer catalyst life. These results strongly indicate that TON type zeolite with 10 -membered rings $(0.46 \mathrm{~nm} \times 0.57 \mathrm{~nm})$ and only straight channels has high potential for the production of propylene from ethanol. The catalytic performance of HTON type zeolite was slightly improved by strontium modification.
\end{abstract}

\section{Keywords}

Ethanol, Propylene, TON type zeolite, 10-Membered ring, Straight channel, Strontium

\section{Introduction}

In recent years, the production of light olefins, especially propylene, from bio-ethanol obtained by the fermentation of biomass has attracted much attention because of the problems of depletion of oil and environmental degradation. Production of hydrocarbons such as ethylene, gasoline, and aromatics from ethanol using solid catalysts has been extensively researched ${ }^{1) \sim 10)}$, whereas ethanol conversion into propylene has received less attention ${ }^{11) \sim 16)}$. Very recently, we investigated ethanol conversion into propylene over various zeolite catalysts, and found that strontium-containing ZSM-5 type zeolite with 10 -membered ring pores provided high propylene yield and high catalytic stability ${ }^{17)}$. Preliminary Rietverld refinement based on the powder $\mathrm{X}$-ray diffraction data suggested that strontium cations are located at the intersections of straight and sinusoidal channels, resulting in suppression of the aromatization of higher olefins, which requires a large reaction space. Therefore, zeolites with 10-membered ring pores and straight channels have high potential for conversion of ethanol into propylene.

TON type zeolites such as Theta-1, NU-10, and ZSM-22 have one-dimensional structures with channels running parallel to the $c$-axis ${ }^{18)}$. The channels are formed from elliptical 10-membered ring systems

\footnotetext{
* To whom correspondence should be addressed.

* E-mail: tsano@hiroshima-u.ac.jp
}

$(0.46 \mathrm{~nm} \times 0.57 \mathrm{~nm})$. TON type zeolites are synthesized using polyamines such as diethylenetriamine and triethylenetetramine as structure-directing agents (SDAs). TON type zeolites have high catalytic performance for hydroisomerization dewaxing ${ }^{19)}$ and propylene oligomerization ${ }^{20)}$, as well as high catalytic performance for the methanol conversion into light olefins ${ }^{21)}$. Our previous study found that TON type zeolites were effectively synthesized from synthesis mixtures containing both $n$-butyl alcohol as an SDA and $\mathrm{KOH}$ as an alkali source ${ }^{22)}$.

This study prepared TON type zeolites with various $\mathrm{SiO}_{2} / \mathrm{Al}_{2} \mathrm{O}_{3}$ ratios using different SDAs, as well as TON type zeolite modified with strontium, and investigated the catalytic performances for ethanol conversion.

\section{Experimental}

\section{1. Synthesis of TON Type Zeolite}

High crystalline TON type zeolites with various $\mathrm{SiO}_{2} / \mathrm{Al}_{2} \mathrm{O}_{3}$ ratios are difficult to synthesize in the presence of polyamines such as diethylenetriamine and triethylenetetramine, so we used three organic molecules as SDAs; 1,6-diaminohexane, 1-ethylpyridinium bromide, and $n$-butyl alcohol. Zeolite synthesis was conducted as follows. Aluminum sulfate $\left(\mathrm{Al}_{2}\left(\mathrm{SO}_{4}\right)_{3} 16 \mathrm{H}_{2} \mathrm{O}\right.$, Wako Pure Chemical Ind., Ltd., Japan), colloidal silica $\left(\mathrm{SiO}_{2}=30.5 \mathrm{wt} \%, \mathrm{Na}_{2} \mathrm{O}=\right.$ $0.4 \mathrm{wt} \%, \mathrm{H}_{2} \mathrm{O}=69.1 \mathrm{wt} \%$, Cataloid SI-30, JGC Catalysts and Chemicals Ltd., Japan), and 1,6-diamino- 
Table 1 Synthesis Conditions and Characteristics of Various HTONs

\begin{tabular}{|c|c|c|c|c|c|c|c|c|}
\hline \multirow[b]{2}{*}{ Sample No. } & \multicolumn{4}{|c|}{ Synthesis conditions ${ }^{\text {a) }}$} & \multicolumn{4}{|c|}{ Product } \\
\hline & $\mathrm{SDA} / \mathrm{SiO}_{2}$ & $\mathrm{SiO}_{2} / \mathrm{Al}_{2} \mathrm{O}_{3}$ & $\mathrm{MOH} / \mathrm{SiO}_{2}$ & $\begin{array}{c}\text { Time } \\
{[\mathrm{h}]}\end{array}$ & $\mathrm{SiO}_{2} / \mathrm{Al}_{2} \mathrm{O}_{3}{ }^{\mathrm{b})}$ & $\begin{array}{l}\text { BET surface } \\
\text { area }^{\mathrm{c})}\left[\mathrm{m}^{2} \mathrm{~g}^{-1}\right]\end{array}$ & $\begin{array}{l}\text { Crystal length } \\
{[\mu \mathrm{m}]}\end{array}$ & Aspect ratio \\
\hline 1 & $0.3(\mathrm{DAH})$ & 60 & $0.3(\mathrm{KOH})$ & 48 & 57 & 213 & $0.1-0.3$ & 4.4 \\
\hline 2 & $1.0(n-\mathrm{BuOH})$ & 75 & $0.2(\mathrm{KOH})$ & 36 & 81 & 93 & $0.3-0.5$ & 9.4 \\
\hline 3 & $0.2(\mathrm{EtPyBr})$ & 140 & $0.3(\mathrm{NaOH})$ & 48 & 112 & 200 & $2.5-3.5$ & 5.4 \\
\hline 4 & 0.2 (EtPyBr) & 180 & $0.3(\mathrm{NaOH})$ & 72 & 140 & 213 & $2.5-3.5$ & 4.4 \\
\hline
\end{tabular}

a) $\mathrm{H}_{2} \mathrm{O} / \mathrm{SiO}_{2}=40$, Temp. $=160{ }^{\circ} \mathrm{C}$.

b) Determined by XRF.

c) Determined by BET method.

hexane (DAH, Tokyo Chemical Ind. Co., Ltd., Japan) were added to a stirred solution of potassium hydroxide (Kanto Chemical Co., Inc., Japan) in deionized water. The hydrogel composition (molar ratio) was as follows: $\mathrm{SiO}_{2} / \mathrm{Al}_{2} \mathrm{O}_{3}=60, \mathrm{OH}^{-} / \mathrm{SiO}_{2}=0.3, \mathrm{DAH} / \mathrm{SiO}_{2}=0.3$, and $\mathrm{H}_{2} \mathrm{O} / \mathrm{SiO}_{2}=40$. 1-Ethylpyridinium bromide (EtPyBr, Tokyo Chemical Ind. Co., Ltd., Japan) and $n$-butyl alcohol ( $n$-BuOH, Tokyo Chemical Ind. Co., Ltd., Japan) were also substituted for DAH. Sodium hydroxide (Kanto Chemical Co., Inc., Japan) was also used as an alkali source. The resultant hydrogel was transferred into a $300-\mathrm{mL}$ stainless-steel autoclave and stirred at $160{ }^{\circ} \mathrm{C}$ for a specified period. The detailed synthesis conditions are listed in Table 1. The precipitated crystals obtained were washed with deionized water, dried at $100{ }^{\circ} \mathrm{C}$ for one night, and calcined in air at $550{ }^{\circ} \mathrm{C}$ for $10 \mathrm{~h}$ to remove the organic materials occluded in the zeolite framework. The zeolite was then protonated in a $1.0 \mathrm{~mol} \mathrm{dm}{ }^{-3}$ hydrochloric acid solution at $60{ }^{\circ} \mathrm{C}$ for $24 \mathrm{~h}$, and calcined in air at $500{ }^{\circ} \mathrm{C}$ for $6 \mathrm{~h}$, yielding a protonated TON type zeolite (HTON).

\section{2. Characterization}

X-ray diffraction (XRD) patterns of the solid products were obtained using a powder X-ray diffractometer (Bruker D8 Advance) with graphite monochromatized $\mathrm{Cu} \mathrm{K} \alpha$ radiation at $40 \mathrm{kV}$ and $30 \mathrm{~mA} . \quad \mathrm{SiO}_{2} / \mathrm{Al}_{2} \mathrm{O}_{3}$ ratios were determined with an X-ray fluorescence analysis apparatus (XRF, Philips PW 2400). A fixed amount of the sample $(0.5 \mathrm{~g})$ was fused with $5 \mathrm{~g}$ of dilithium tetraborate $\left(\mathrm{Li}_{2} \mathrm{~B}_{4} \mathrm{O}_{7}\right)$ at $1100{ }^{\circ} \mathrm{C}$. The crystal morphology was observed with a scanning electron microscope (SEM, HITACHI S-4800). The thermal analysis was carried out using a TG/DTA apparatus (SSC/5200, Seiko Instruments, Inc.). The sample ( $c a$. $3 \mathrm{mg})$ was heated in a flow of air $\left(50 \mathrm{~mL} \mathrm{~min}^{-1}\right)$ at $10{ }^{\circ} \mathrm{C} \mathrm{min}^{-1}$ from room temperature to $800{ }^{\circ} \mathrm{C}$. ${ }^{27} \mathrm{Al}$ magic angle spinning (MAS) NMR and ${ }^{29} \mathrm{Si}$ MAS NMR spectra were recorded at $104.2 \mathrm{MHz}$ and $79.5 \mathrm{MHz}$, respectively, with a Varian 600PS solid NMR spectrometer, using a 3.2-mm diameter zirconia rotor spun at $15 \mathrm{kHz}$ for ${ }^{27} \mathrm{Al}$ MAS NMR and a 5-mm diameter zirconia rotor spun at $6 \mathrm{kHz}$ for ${ }^{29} \mathrm{Si}$ MAS NMR. The spectra were acquired using $2.3 \mu$ s pulses,
1 s recycle delay, and 1000 scans for ${ }^{27} \mathrm{Al}$ MAS NMR, and $5 \mu$ s pulses, $100 \mathrm{~s}$ recycle delay, and 1000 scans for ${ }^{29} \mathrm{Si} \mathrm{MAS}$ NMR. $\mathrm{Al}\left(\mathrm{NO}_{3}\right)_{3} \cdot 9 \mathrm{H}_{2} \mathrm{O}$ and 3-(trimethylsilyl)propionic-2,2,3,3- $\mathrm{d}_{4}$ acid sodium salt were used as chemical shift references for ${ }^{27} \mathrm{Al}$ and ${ }^{29} \mathrm{Si}$ MAS NMR, respectively. Prior to the ${ }^{27} \mathrm{Al}$ MAS NMR measurements, the samples were moisture-equilibrated over a saturated solution of $\mathrm{NH}_{4} \mathrm{Cl}$ for $24 \mathrm{~h}$. Nitrogen adsorption isotherms were obtained at $-196{ }^{\circ} \mathrm{C}$ using a conventional volumetric apparatus (BELSORP-max, Bel Japan Inc.). Prior to adsorption measurements, the calcined samples ( $c a .0 .1 \mathrm{~g}$ ) were evacuated at $400{ }^{\circ} \mathrm{C}$ for $10 \mathrm{~h}$. IR spectra were recorded using a FTIR spectrometer (JEOL JIR-7000) with a resolution of $4 \mathrm{~cm}^{-1}$ at room temperature. For measurements in the $\mathrm{OH}$ groups stretching region, the sample was pressed into a self-supporting thin wafer ( $\left.c a .6 .4 \mathrm{mg} \mathrm{cm}^{-2}\right)$ and placed into a quartz IR cell equipped with $\mathrm{CaF}_{2}$ windows. Prior to measurement, each sample was dehydrated under vacuum at $400{ }^{\circ} \mathrm{C}$ for $2 \mathrm{~h}$. The distribution of acidity on the zeolites was measured in the range from 150 to $700{ }^{\circ} \mathrm{C}$ by temperature-programmed desorption of ammonia ( $\mathrm{NH}_{3}$-TPD, CAT-B-82 $\mathrm{NH}_{3}$-TPD, Bel Japan Inc.). Helium was used as a carrier gas, and the samples were heated at a rate of $10{ }^{\circ} \mathrm{C} \mathrm{min}^{-1}$.

\section{3. Ethanol Conversion}

Ethanol conversion was carried out at $550{ }^{\circ} \mathrm{C}$ with $W / F$

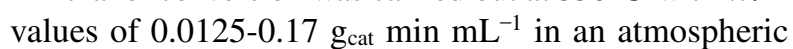
pressure flow system. A specified amount of zeolite (12-24 mesh) was retained by placing quartz wool at the center of a quartz reactor with a $10-\mathrm{mm}$ inner diameter. A thermocouple inserted into the center of the catalyst bed was used to measure the temperature during the reaction. The catalyst was activated at $500{ }^{\circ} \mathrm{C}$ for $1 \mathrm{~h}$ under nitrogen flow prior to carrying out the reaction. Ethanol $(>99.5 \%$, Wako Pure Chemical Ind. Ltd., Japan) was pumped into the vaporizer and mixed with $\mathrm{N}_{2}$ at a total flow rate of $20 \mathrm{~mL} \mathrm{~min}^{-1}$ $\left(\mathrm{C}_{2} \mathrm{H}_{5} \mathrm{OH} / \mathrm{N}_{2}=50 / 50 \mathrm{~mol} \%\right)$. The gaseous products were analyzed using an on-line GC equipped with TCD- and FID-type detectors on a Shincarbon ST (Shinwa Chemical Ind., Ltd., Japan) column for $\mathrm{N}_{2}, \mathrm{H}_{2}$, and $\mathrm{CO}_{2}$; on a Gaskuropack 54 (GL Sciences Inc., 


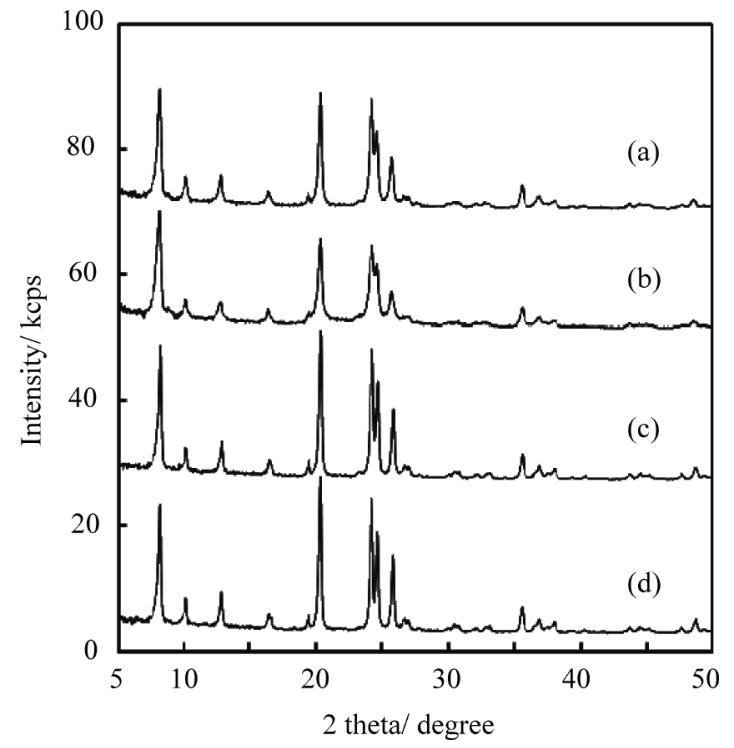

Fig. 1 XRD Patterns of Various HTONs Synthesized Using (a) DAH (Sample No. 1), (b) $n$-BuOH (Sample No. 2), (c) EtPyBr (Sample No. 3), and (d) EtPyBr (Sample No. 4)

Japan) column for ethanol; and on a RT-alumina PLOT (Restek Co., USA) column for $\mathrm{C}_{1}-\mathrm{C}_{4}$ hydrocarbons. The product yields were calculated using $\mathrm{N}_{2}$ as an internal standard.

\section{Results and Discussion}

\section{1. Ethanol Conversion over HTON}

In general, the product distribution in the zeolitic ethanol conversion process depends strongly on the acidity as well as the channel structure of the zeolite. To investigate the effect of the acidity on the reaction behavior of ethanol conversion on HTON zeolite catalyst, HTONs with various $\mathrm{SiO}_{2} / \mathrm{Al}_{2} \mathrm{O}_{3}$ ratios were synthesized using various types of SDAs for use in the ethanol conversion reaction. All synthesized HTONs had well-defined TON type zeolite structures, as demonstrated by their XRD patterns (Fig. 1). There were no diffraction peaks other than those of the TON zeolite structure, although the HTON synthesized using $n$ - $\mathrm{BuOH}$ showed slightly broad peaks and relatively weak peak intensities. Figure 2 shows the SEM images of these HTONs. After thorough observation, we did not find any crystals or amorphous materials other than the needle-like crystals characteristic of TON type $z^{2} \operatorname{lite}^{22) \sim 24)}$. The crystal lengths and aspect ratios are summarized in Table 1. Table 1 also shows that the BET surface areas of HTONs synthesized using DAH and EtPyBr as SDAs (Sample Nos. 1, 3, and 4) were larger than $200 \mathrm{~m}^{2} \mathrm{~g}^{-1}$ and consistent with reported values $^{24), 25)}$. On the other hand, the BET surface area of HTON prepared using $n$-BuOH (Sample No. 2) was below $100 \mathrm{~m}^{2} \mathrm{~g}^{-1}$, which was probably due to the slightly
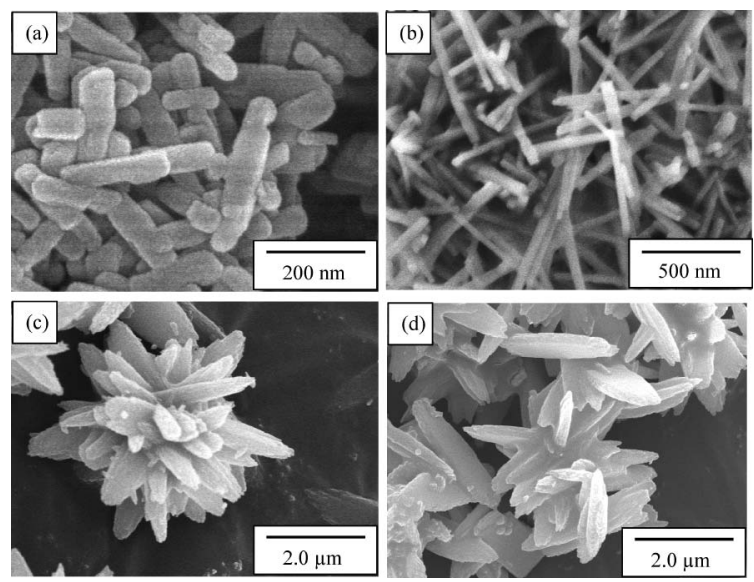

Fig. 2 SEM Images of Various HTONs Synthesized Using (a) DAH (Sample No. 1), (b) $n$-BuOH (Sample No. 2), (c) EtPyBr (Sample No. 3), and (d) EtPyBr (Sample No. 4)

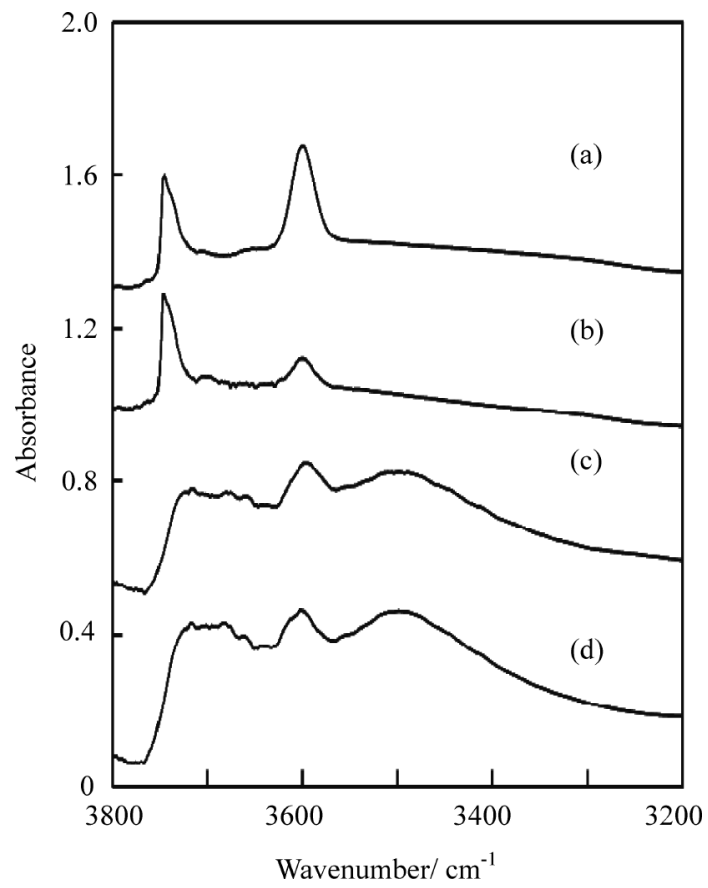

Fig. 3 FT-IR Spectra of Various HTONs Synthesized Using (a) DAH (Sample No. 1), (b) $n$-BuOH (Sample No. 2), (c) EtPyBr (Sample No. 3), and (d) EtPyBr (Sample No. 4)

lower crystallinity.

The acidic properties of HTONs were evaluated by FT-IR and $\mathrm{NH}_{3}$-TPD. The FT-IR spectra in the $\mathrm{OH}$ region of various HTON samples are shown in Fig. 3. The IR spectra of HTONs synthesized using DAH and $n$-BuOH showed two sharp peaks at approximately 3740 and $3610 \mathrm{~cm}^{-1}$. The former was assigned to the isolated silanol group, whereas the later was attributed to an acidic bridging $\mathrm{OH}$ group of $\mathrm{Si}(\mathrm{OH}) \mathrm{Al}$, forming a Brønsted acid site. On the other hand, in the IR spectra of HTONs synthesized using EtPyBr, a broad peak 
of near $3500 \mathrm{~cm}^{-1}$ as well as the two peaks at 3610 and $3740 \mathrm{~cm}^{-1}$ were clealy observed. The broad peak of near $3500 \mathrm{~cm}^{-1}$ was attributed to hydrogen-bonded adjacent hydroxyl groups, indicating the presence of structural defects ${ }^{26)}$. The intensity of the peak at $3610 \mathrm{~cm}^{-1}$, assigned to the Brønsted acid sites, decreased with higher $\mathrm{SiO}_{2} / \mathrm{Al}_{2} \mathrm{O}_{3}$ ratio of zeolite framework. The lower number of Brønsted acid sites was also confirmed from the $\mathrm{NH}_{3}$-TPD curves of these zeolites with different $\mathrm{SiO}_{2} / \mathrm{Al}_{2} \mathrm{O}_{3}$ ratios (Fig. 4).

Next, we investigated the catalytic performance of

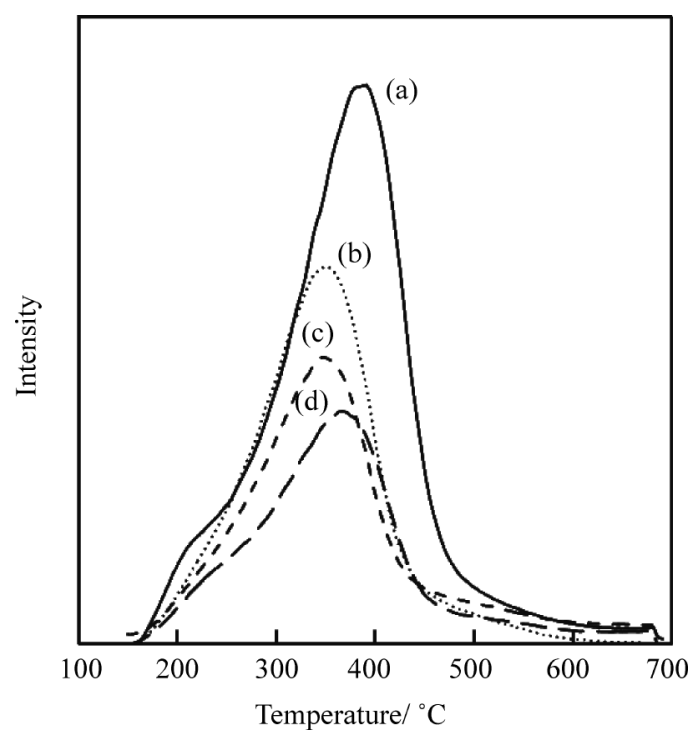

(a) Sample No. 1, (b) Sample No. 3, (c) Sample No. 4, and (d) Sr/ $\operatorname{HTON}\left(\mathrm{SiO}_{2} / \mathrm{Al}_{2} \mathrm{O}_{3}=140, \mathrm{Sr} / \mathrm{Al}=0.2\right)$.

Fig. $4 \mathrm{NH}_{3}$-TPD Curves of Various HTON Type Zeolites obtained HTONs for ethanol conversion. In the preliminary experiments, higher propylene yield was obtained at $550{ }^{\circ} \mathrm{C}$ as compared to $500{ }^{\circ} \mathrm{C}$. Therefore, the reaction temperature was fixed at $550{ }^{\circ} \mathrm{C}$. Of course, to compare the results directly with those for HZSM-5 zeolite catalyst obtained in our previous study ${ }^{17)}$, the reaction temperature should have been fixed at $500{ }^{\circ} \mathrm{C}$. We wished to optimize the propylene yield in the present study.

Figure 5 shows the relationship between the contact time $(W / F)$ and the ethylene and propylene yields over HTONs with various $\mathrm{SiO}_{2} / \mathrm{Al}_{2} \mathrm{O}_{3}$ ratios. The ethylene and propylene yields are the initial values after $0.5 \mathrm{~h}$ of time-on-stream. The ethanol conversion was $100 \mathrm{C}-\%$ for all zeolites. The ethylene and propylene yields strongly depended on the $\mathrm{SiO}_{2} / \mathrm{Al}_{2} \mathrm{O}_{3}$ ratio and the $W / F$ value. The ethylene yield decreased with higher $W / F$ value, whereas the propylene yield reached a maximum value of $c a$. $25 \mathrm{C}-\%$. Although the $\mathrm{SiO}_{2} / \mathrm{Al}_{2} \mathrm{O}_{3}$ ratio did not affect the maximum value of the propylene yield, higher $W / F$ values were required for HTONs with higher $\mathrm{SiO}_{2} / \mathrm{Al}_{2} \mathrm{O}_{3}$ ratios. In general, ethanol is considered to be first converted into ethylene and subsequently to higher hydrocarbons by oligomerization. Propylene is mainly formed by cracking of the higher hydrocarbons. Therefore, the propylene yield is thought to be related to the oligomerization and cracking abilities of acidic sites. The number of acidic sites decreases with higher $\mathrm{SiO}_{2} / \mathrm{Al}_{2} \mathrm{O}_{3}$ ratio of the zeolite framework (Figs. 3 and 4), so higher $W / F$ values are required for HTONs with higher $\mathrm{SiO}_{2} / \mathrm{Al}_{2} \mathrm{O}_{3}$ ratios. These results indicate that high propylene yield can be obtained over zeolite catalysts even with only straight channels. Table 2 lists the detailed product distribu-
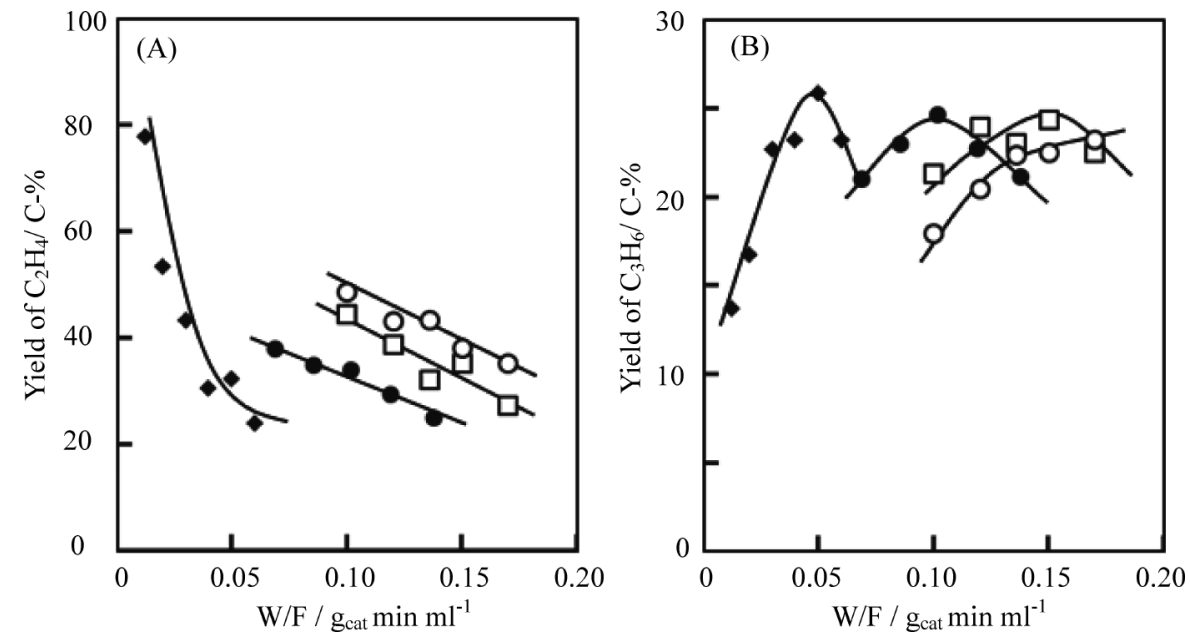

Yields of $\mathrm{C}_{2} \mathrm{H}_{4}$ and $\mathrm{C}_{3} \mathrm{H}_{6}$ are initial values after $0.5 \mathrm{~h}$ of time-on-stream.

Fig. 5 Conversion of Ethanol into Light Olefins over Various HTONs Synthesized Using ( $)$ DAH (Sample No. 1), (○) n-BuOH (Sample No. 2), (O) EtPyBr (Sample No. 3), and ( $\square$ ) EtPyBr (Sample No. 4) 
Table 2 Product Distributions after $0.5 \mathrm{~h}$ of Time-on-stream over Various HTONs

\begin{tabular}{|c|c|c|c|c|c|c|c|}
\hline \multirow{2}{*}{ Sample No. } & \multirow{2}{*}{$\mathrm{SiO}_{2} / \mathrm{Al}_{2} \mathrm{O}_{3}$} & \multirow{2}{*}{$\begin{array}{c}W / F \\
{\left[\mathrm{~g}_{\text {cat }} \min \mathrm{mL}^{-1}\right]}\end{array}$} & \multicolumn{5}{|c|}{ Product distribution [C-\%] } \\
\hline & & & $\mathrm{C}_{2} \mathrm{H}_{4}$ & $\mathrm{C}_{3} \mathrm{H}_{6}$ & $\mathrm{C}_{4}$ olefins & $\mathrm{C}_{2}-\mathrm{C}_{4}$ paraffins & $\mathrm{C}_{5}{ }^{+}$ \\
\hline 1 & 57 & 0.05 & 32.2 & 25.8 & 11.9 & 8.6 & 21.5 \\
\hline 2 & 81 & 0.17 & 35.2 & 23.3 & 11.8 & 6.7 & 23.0 \\
\hline 3 & 112 & 0.10 & 33.8 & 24.6 & 11.0 & 9.1 & 21.4 \\
\hline 4 & 140 & 0.15 & 35.2 & 24.4 & 11.9 & 8.1 & 20.4 \\
\hline
\end{tabular}

Reaction temp. $=550{ }^{\circ} \mathrm{C}$.

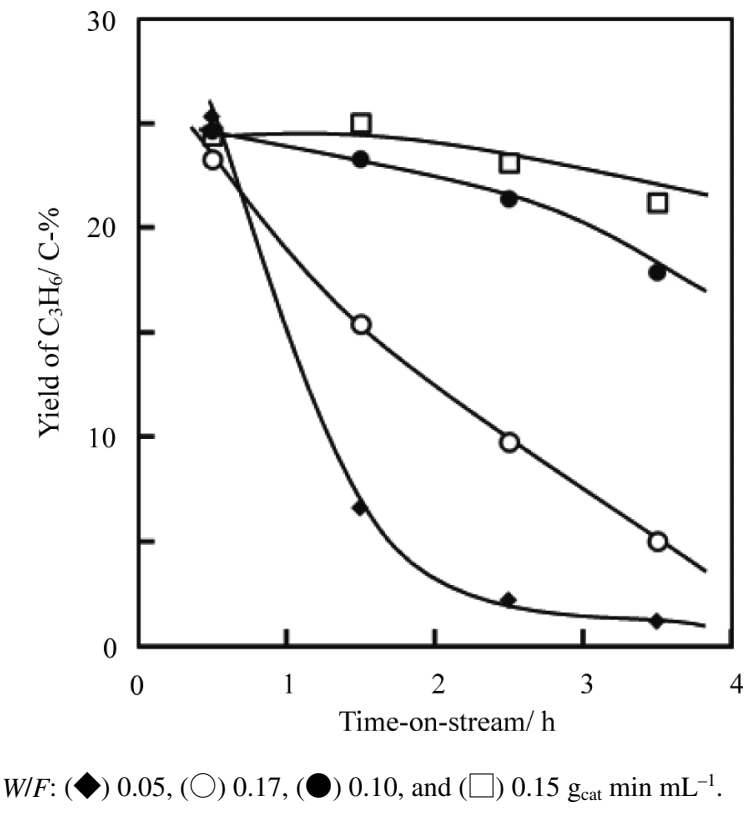

Fig. 6 Effect of Time-on-stream on $\mathrm{C}_{3} \mathrm{H}_{6}$ Yield over Various HTONs Synthesized Using ( DAH (Sample No. 1), $(\bigcirc)$ n-BuOH (Sample No. 2), (O) EtPyBr (Sample No. 3), and ( $\square$ ) EtPyBr (Sample No. 4 )

tions after $0.5 \mathrm{~h}$ of time-on-stream using various HTONs when the maximum propylene yield was obtained. No differences in the product distribution were observed, despite using various HTONs with different $\mathrm{SiO}_{2} / \mathrm{Al}_{2} \mathrm{O}_{3}$ ratio, BET surface area, crystal size, and aspect ratio, suggesting that the chemical properties of the acid sites were the same. These findings show that TON type zeolite with 10-membered ring pores and straight channels has high potential for the production of propylene from ethanol.

Generally, deactivation of a zeolite catalyst occurs predominantly through two causes: the poisoning of acid sites due to the accumulation of carbonaceous deposits, and structure degradation of zeolite due to elimination of aluminum in the zeolite framework, resulting in reduction of the number of acidic sites. The reduction of acidic sites is related to the suppression of oligomerization and cracking, resulting in lower propylene yields. Therefore, the catalytic stability of HTONs was investigated. Figure 6 shows the effect of timeon-stream on propylene yield over HTONs with various
$\mathrm{SiO}_{2} / \mathrm{Al}_{2} \mathrm{O}_{3}$ ratios. In order to maintain constant initial propylene yield, the $W / F$ values were set at $0.05 \mathrm{~g}_{\text {cat }}$ min $\mathrm{mL}^{-1}$ for $\mathrm{HTON}$ with $\mathrm{SiO}_{2} / \mathrm{Al}_{2} \mathrm{O}_{3}$ ratio of 57 (Sample No. 1), $0.17 \mathrm{~g}_{\text {cat }} \min \mathrm{mL}^{-1}$ for HTON with $\mathrm{SiO}_{2} / \mathrm{Al}_{2} \mathrm{O}_{3}$ ratio of 81 (Sample No. 2), $0.10 \mathrm{~g}_{\text {cat }}$ min $\mathrm{mL}^{-1}$ for HTON with $\mathrm{SiO}_{2} / \mathrm{Al}_{2} \mathrm{O}_{3}$ ratio of 112 (Sample No. 3), and $0.15 \mathrm{~g}_{\text {cat }}$ min $\mathrm{mL}^{-1}$ for HTON with $\mathrm{SiO}_{2} /$ $\mathrm{Al}_{2} \mathrm{O}_{3}$ ratio of 140 (Sample No. 4). The propylene yields for HTONs with $\mathrm{SiO}_{2} / \mathrm{Al}_{2} \mathrm{O}_{3}$ ratios of 57 and 81 rapidly decreased with time-on-stream, whereas slight decrease was observed for HTONs with $\mathrm{SiO}_{2} / \mathrm{Al}_{2} \mathrm{O}_{3}$ ratios of 112 and 140. The ethanol conversion was $100 \mathrm{C}-\%$ for all zeolites, even after $3.5 \mathrm{~h}$ of time-onstream. The amounts of carbonaceous deposits after the reaction evaluated by TG analysis were $4.7 \mathrm{wt} \%$ for HTON with $\mathrm{SiO}_{2} / \mathrm{Al}_{2} \mathrm{O}_{3}$ ratio of 57 and $3.0 \mathrm{wt} \%$ for HTON with $\mathrm{SiO}_{2} / \mathrm{Al}_{2} \mathrm{O}_{3}$ ratio of 140 . This difference was not so large. In order to clarify the difference in deactivation behavior based on propylene yield, XRD patterns and FT-IR spectra of HTONs with $\mathrm{SiO}_{2} / \mathrm{Al}_{2} \mathrm{O}_{3}$ ratios of 57 and 140 after the reaction were measured. Although slight decreases in the intensities of diffraction peaks were observed for the XRD patterns of HTONs after the reaction, followed by calcination in air at $550{ }^{\circ} \mathrm{C}$ for $10 \mathrm{~h}$ to remove carbonaceous deposits, there were no diffraction peaks other than those of the TON zeolite structure (Fig. 7). On the other hand, the FT-IR spectra showed a large difference. As can be seen in Fig. 8(A), the peak at $3610 \mathrm{~cm}^{-1}$ assigned to an acidic bridging $\mathrm{OH}$ group of $\mathrm{Si}(\mathrm{OH}) \mathrm{Al}$ almost completely disappeared in the FT-IR spectrum of HTON with $\mathrm{SiO}_{2} / \mathrm{Al}_{2} \mathrm{O}_{3}$ ratio of 57 after the reaction. Marked decrease in the intensity of the peak at $3610 \mathrm{~cm}^{-1}$ was observed after the reaction over HTON with $\mathrm{SiO}_{2} / \mathrm{Al}_{2} \mathrm{O}_{3}$ ratio of 140 , but the peak was clearly observed (Fig. 8(B)). These results suggest that the difference in the catalytic stability is related to elimination of aluminum in the framework, or dealumination. To further confirm this supposition, the ${ }^{27} \mathrm{Al}$ and ${ }^{29} \mathrm{Si}$ MAS NMR spectra of these HTONs before and after the reaction were measured. As can be seen in Fig. 9, the shape peak assigned to the tetrahedrally coordinated framework aluminum species was observed at $c a$. $52 \mathrm{ppm}$. A very weak peak corresponding to the octahedrally coordinated aluminum species, the extraframework aluminum species, was also observed at 

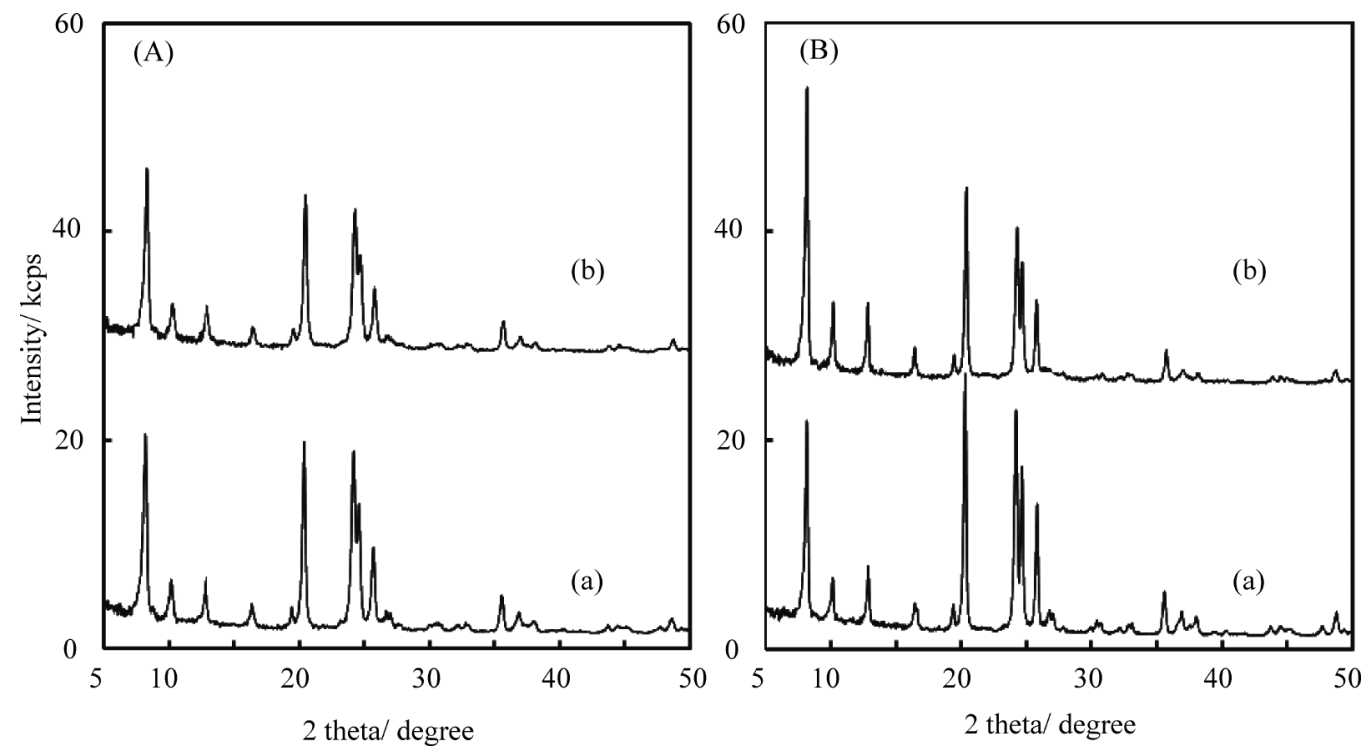

Fig. 7 XRD Patterns of (A) HTON with $\mathrm{SiO}_{2} / \mathrm{Al}_{2} \mathrm{O}_{3}$ Ratio of 57 and (B) HTON with $\mathrm{SiO}_{2} / \mathrm{Al}_{2} \mathrm{O}_{3} \mathrm{Ratio}$ of 140 (a) before and (b) after the Reaction
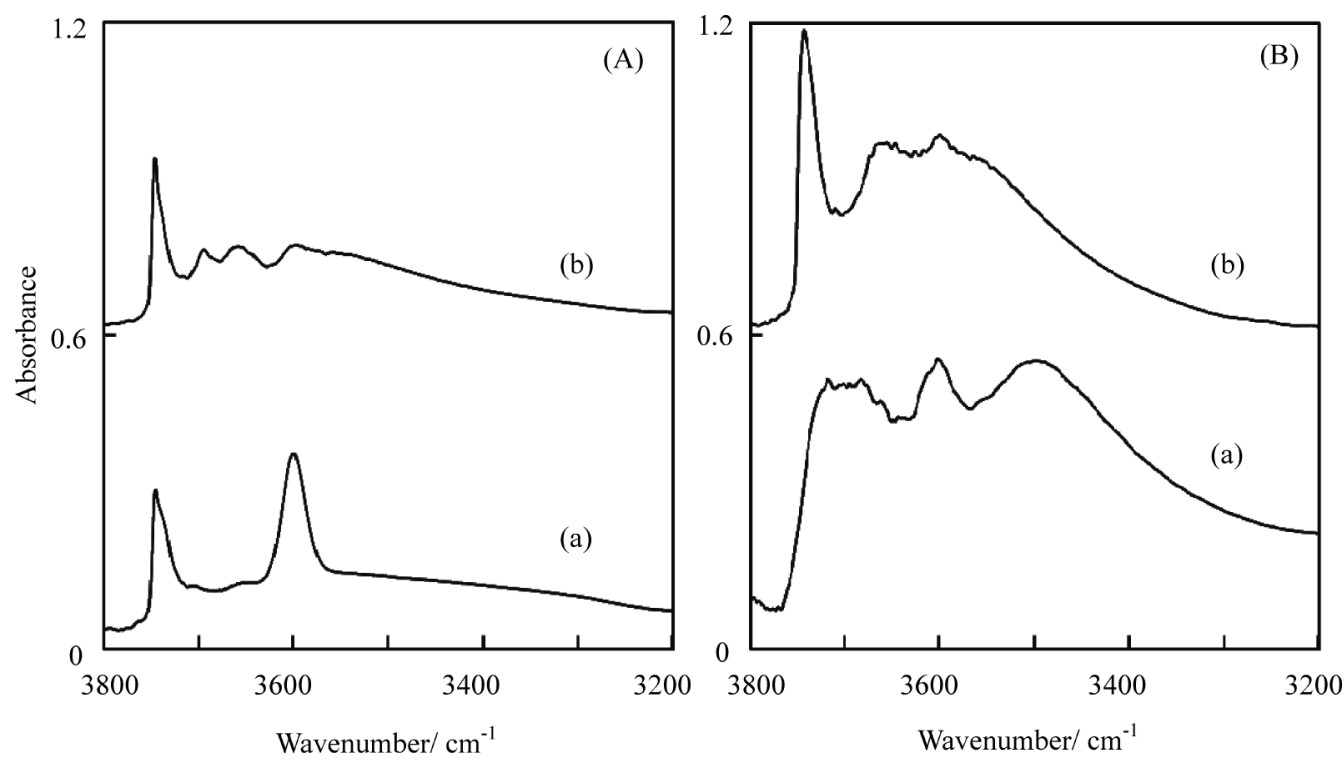

Fig. 8 FT-IR Spectra of (A) HTON with $\mathrm{SiO}_{2} / \mathrm{Al}_{2} \mathrm{O}_{3}$ Ratio of 57 and (B) HTON with $\mathrm{SiO}_{2} / \mathrm{Al}_{2} \mathrm{O}_{3}$ Ratio of 140 (a) before and (b) after the Reaction

around 0 ppm. In the case of $\mathrm{HTON}$ with $\mathrm{SiO}_{2} / \mathrm{Al}_{2} \mathrm{O}_{3}$ ratio of 57, the intensity of the peak at 52 ppm was considerably reduced after the reaction. Therefore, severe dealumination by water generated by dehydration of ethanol occurred during the reaction. On the other hand, reduction of the peak intensity at $52 \mathrm{ppm}$ was smaller for HTON with $\mathrm{SiO}_{2} / \mathrm{Al}_{2} \mathrm{O}_{3}$ ratio of 140 compared to $\mathrm{HTON}$ with $\mathrm{SiO}_{2} / \mathrm{Al}_{2} \mathrm{O}_{3}$ ratio of 57 , indicating the high hydrothermal stability of high silica HTON zeolite. Severe dealumination of HTON with $\mathrm{SiO}_{2} /$ $\mathrm{Al}_{2} \mathrm{O}_{3}$ ratio of 57 was also confirmed from the ${ }^{29} \mathrm{Si}$ MAS NMR spectra, as the peak at -105 ppm assigned to $\mathrm{Q}^{4}(1 \mathrm{Al})$ disappeared completely after the reaction (Fig. 10).

\section{2. Ethanol Conversion over HTON Modified with Strontium}

As described in the introduction, we recently found that HZSM-5 zeolite containing strontium provided high propylene yield and high catalytic stability. Therefore, to enhance the catalytic performance of HTON, we prepared strontium-modified HTONs and evaluated their ethanol conversion efficiency. Strontium-modified HTONs with $\mathrm{SiO}_{2} / \mathrm{Al}_{2} \mathrm{O}_{3}$ ratio of $140, \mathrm{Sr} / \mathrm{HTON}$, were prepared by the impregnation 

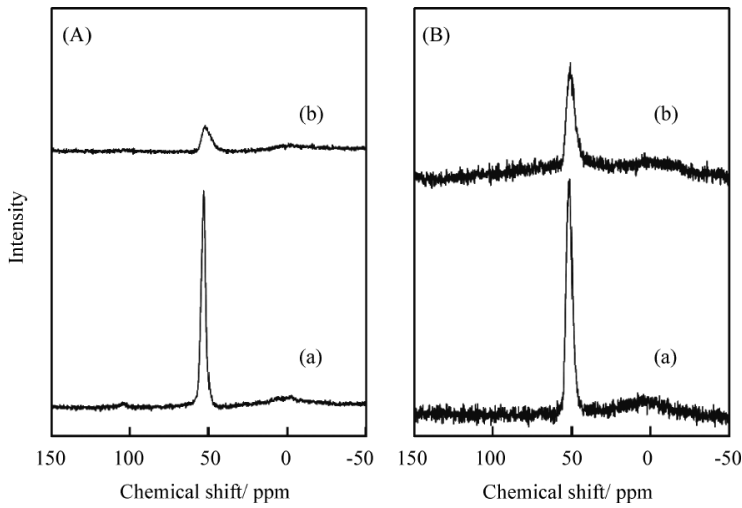

Fig. $9{ }^{27} \mathrm{Al}$ MAS NMR Spectra of (A) HTON with $\mathrm{SiO}_{2} / \mathrm{Al}_{2} \mathrm{O}_{3}$ Ratio of 57 and (B) HTON with $\mathrm{SiO}_{2} / \mathrm{Al}_{2} \mathrm{O}_{3}$ Ratio of 140 (a) before and (b) after the Reaction
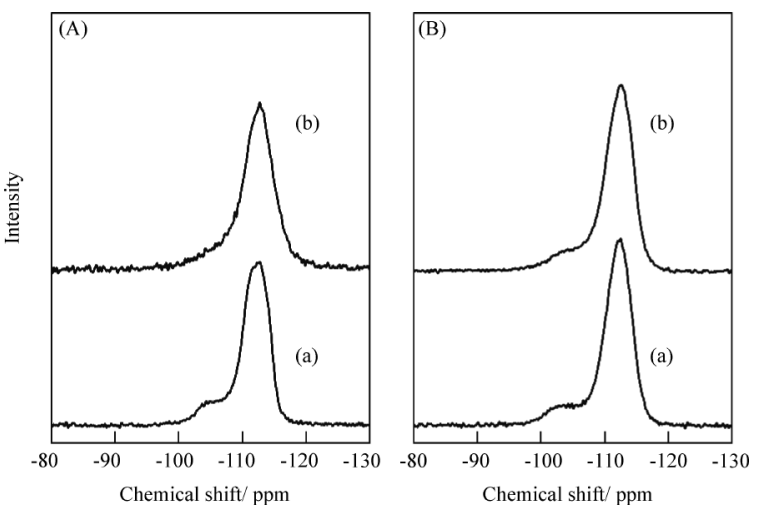

Fig. $10{ }^{29} \mathrm{Si}$ MAS NMR Spectra of (A) HTON with $\mathrm{SiO}_{2} / \mathrm{Al}_{2} \mathrm{O}_{3}$ Ratio of 57 and (B) HTON with $\mathrm{SiO}_{2} / \mathrm{Al}_{2} \mathrm{O}_{3}$ Ratio of 140 (a) before and (b) after the Reaction

method from aqueous solution of $0.02 \mathrm{M}$ $\mathrm{Sr}\left(\mathrm{CH}_{3} \mathrm{COO}\right)_{2}$, and then calcined in air at $500{ }^{\circ} \mathrm{C}$ for $6 \mathrm{~h}$. Figure 11 shows the relationship between the $\mathrm{Sr} /$ $\mathrm{Al}$ ratio and the product yields after $0.5 \mathrm{~h}$ of time-onstream at a reaction temperature of $550{ }^{\circ} \mathrm{C}$. Taking into account the slight decrease in the number of acidic sites of HTON by Sr modification, the $W / F$ was

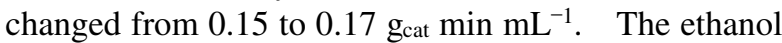
conversion was $100 \mathrm{C}-\%$ for all zeolite. The propylene and butenes yields increased with higher $\mathrm{Sr} / \mathrm{Al}$ ratio and reached maximum values at the $\mathrm{Sr} / \mathrm{Al}$ ratio of $c a$. 0.2. On the other hand, the ethylene yield increased monotonously with the $\mathrm{Sr} / \mathrm{Al}$ ratio, indicating that oligomerization of ethylene produced by dehydration of ethanol was suppressed by the strontium modification, probably due to the lower number of strong acid sites caused by strontium cation-exchange with the proton of the acidic bridging $\mathrm{OH}$ group of $\mathrm{Si}(\mathrm{OH}) \mathrm{Al}$ (Brønsted acid site). The reduction in the strong acid sites was confirmed from the $\mathrm{NH}_{3}$-TPD curve of $\mathrm{Sr} / \mathrm{HTON}$ (Fig. 4). To further clarify this observation, the IR spectra of Sr/HTON were measured. Clear decrease

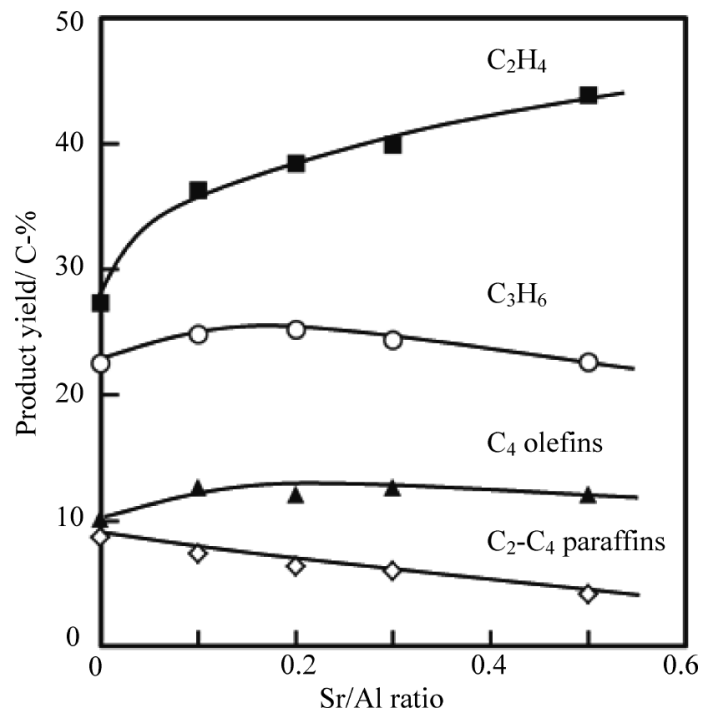

Reaction conditions: temp. $=550{ }^{\circ} \mathrm{C}, W / F=0.17 \mathrm{~g}_{\text {cat }} \min \mathrm{mL}^{-1}$. Product yields are initial values after $0.5 \mathrm{~h}$ of time-on-stream.

Fig. 11 Effect of $\mathrm{Sr} / \mathrm{Al}$ Ratio of $\mathrm{Sr} / \mathrm{HTON}$ with $\mathrm{SiO}_{2} / \mathrm{Al}_{2} \mathrm{O}_{3}$ Ratio of 140 on Product Yields

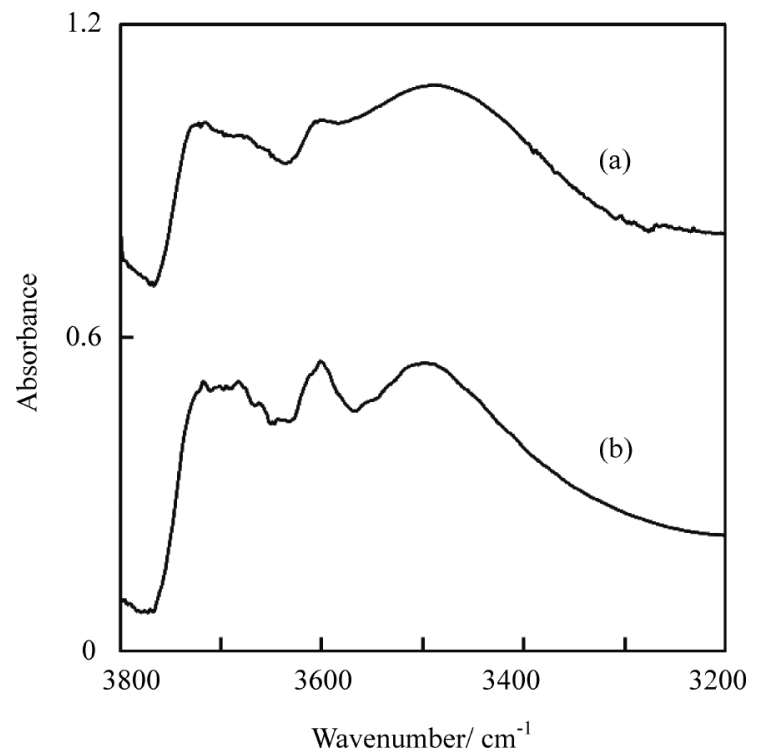

Fig. 12 FT-IR Spectra of (a) $\mathrm{Sr} / \mathrm{HTON}\left(\mathrm{SiO}_{2} / \mathrm{Al}_{2} \mathrm{O}_{3}=140, \mathrm{Sr} / \mathrm{Al}=\right.$ $0.2)$ and (b) $\mathrm{HTON}\left(\mathrm{SiO}_{2} / \mathrm{Al}_{2} \mathrm{O}_{3}=140\right)$

in the intensity of the peak at $3610 \mathrm{~cm}^{-1}$ by $\mathrm{Sr}$ modificatiuion was observed, indicating fewer Brønsted acid sites (Fig. 12).

Figure 13(A) shows the effect of time-on-stream on propylene yield over $\mathrm{Sr} / \mathrm{HTON}$ with $\mathrm{Sr} / \mathrm{Al}$ ratio of 0.2 . For comparison, the propylene yield over HTON without strontium modification, and the propylene yields over HZSM-5 $\left(\mathrm{SiO}_{2} / \mathrm{Al}_{2} \mathrm{O}_{3}=184\right)$ and $\mathrm{Sr} / \mathrm{HZSM}$ $5\left(\mathrm{SiO}_{2} / \mathrm{Al}_{2} \mathrm{O}_{3}=203, \mathrm{Sr} / \mathrm{Al}=0.1\right)$ in the previous study are also shown $(\text { Fig. 13(B) })^{17)}$. Decreased propylene yield was observed for both HTON and Sr/HTON after 

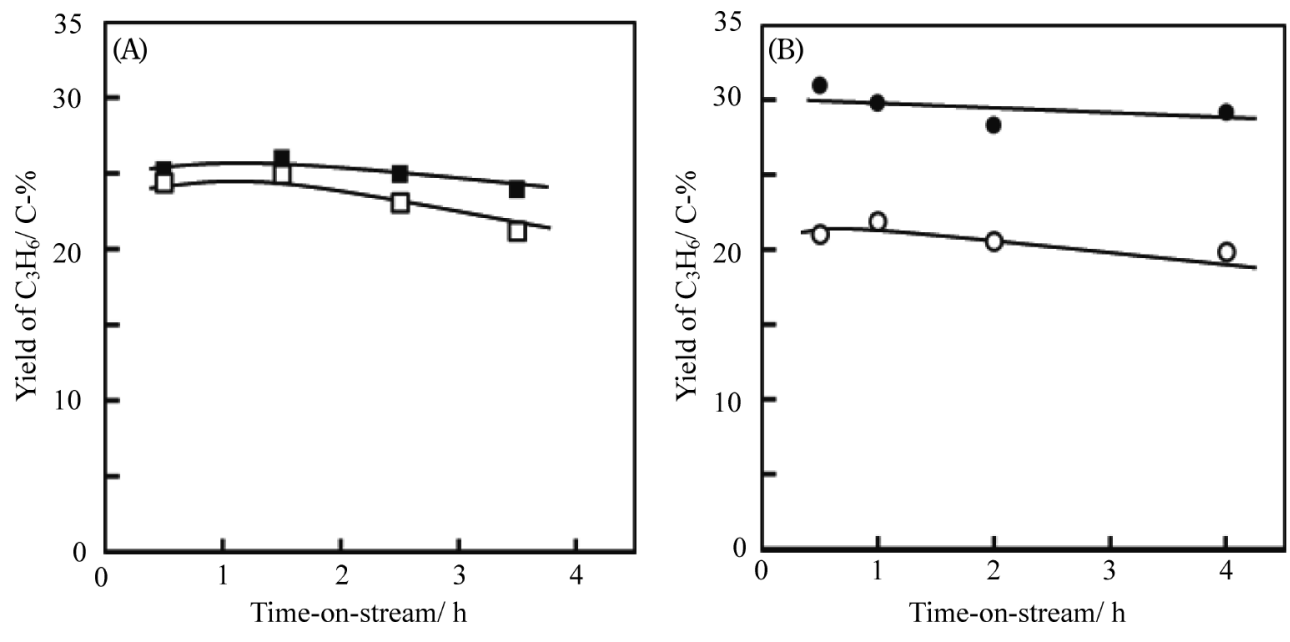

Reaction conditions: temp. $=(\square),(\square) 550{ }^{\circ} \mathrm{C}$,

(O) $500{ }^{\circ} \mathrm{C}, W / F=$

$0.17,(\square) 0.15$

$(\mathrm{O})$ and $(\bigcirc)$ $0.03 \mathrm{~g}_{\text {cat }} \min \mathrm{mL}^{-1}$.

Fig. 13 Effect of Time-on-stream on $\mathrm{C}_{3} \mathrm{H}_{6}$ Yield over (A)

$\mathrm{Sr} / \mathrm{HTON}\left(\mathrm{SiO}_{2} / \mathrm{Al}_{2} \mathrm{O}_{3}=140, \mathrm{Sr} / \mathrm{Al}=0.2\right)$, and ( $\square$ ) HTON $\left(\mathrm{SiO}_{2} / \mathrm{Al}_{2} \mathrm{O}_{3}=140\right)$, and (B) HZSM-5 $\left(\mathrm{SiO}_{2} / \mathrm{Al}_{2} \mathrm{O}_{3}=184\right)$

$3.5 \mathrm{~h}$ of time-on-stream. Although the reduction in propylene yield was slightly improved by strontium modification, no remarkable improvement of catalyst stability occurred, as observed in the case of Sr/HZSM5. In order to clarify this difference, $\mathrm{N}_{2}$ adsorption measurement was performed for Sr/HTON. The BET surface area of $\mathrm{Sr} / \mathrm{HTON}\left(190 \mathrm{~m}^{2} \mathrm{~g}^{-1}\right)$ was slightly smaller than that of HTON $\left(213 \mathrm{~m}^{2} \mathrm{~g}^{-1}\right)$. The reduction in the BET surface area of $\mathrm{Sr} / \mathrm{HTON}$ is probably due to blocking of some straight channels by $\mathrm{Sr}$ incorporation, resulting in diffusion limitation of the reactants and products. In the case of Sr/HZSM-5, such decrease in the surface area was not observed ${ }^{17)}$. These results suggested that $\mathrm{Sr}$ cations are located at the intersections of the straight and sinusoidal channels of HZSM-5.

The product distribution in the zeolitic ethanol conversion process is generally accepted to be strongly dependent on the acidity as well as the channel structure of the zeolite ${ }^{13)}$, and ethanol is considered to be first converted to ethylene and subsequently to higher hydrocarbons ${ }^{15)}$. The initial ethylene and propylene yields are thought to be related to the oligomerization abilities of the zeolite acid sites. Therefore, the effect of ethylene consumption on the propylene yield was investigated. The propylene yield was plotted against the ethylene consumption rate (C-\%, 100-yield of ethylene), as shown in Fig. 14. For comparison, the results over HZSM-5 $\left(\mathrm{SiO}_{2} / \mathrm{Al}_{2} \mathrm{O}_{3}=184\right)$ and Sr/HZSM-5 $\left(\mathrm{SiO}_{2} /\right.$ $\left.\mathrm{Al}_{2} \mathrm{O}_{3}=203, \mathrm{Sr} / \mathrm{Al}=0.1\right)$ are also shown. To obtain a range of ethylene consumption values, the ethanol conversion reaction was carried out at $550{ }^{\circ} \mathrm{C}$ by varying the $W / F$ ratio. For all zeolite catalysts, the propylene yield increased with higher ethylene consumption rate

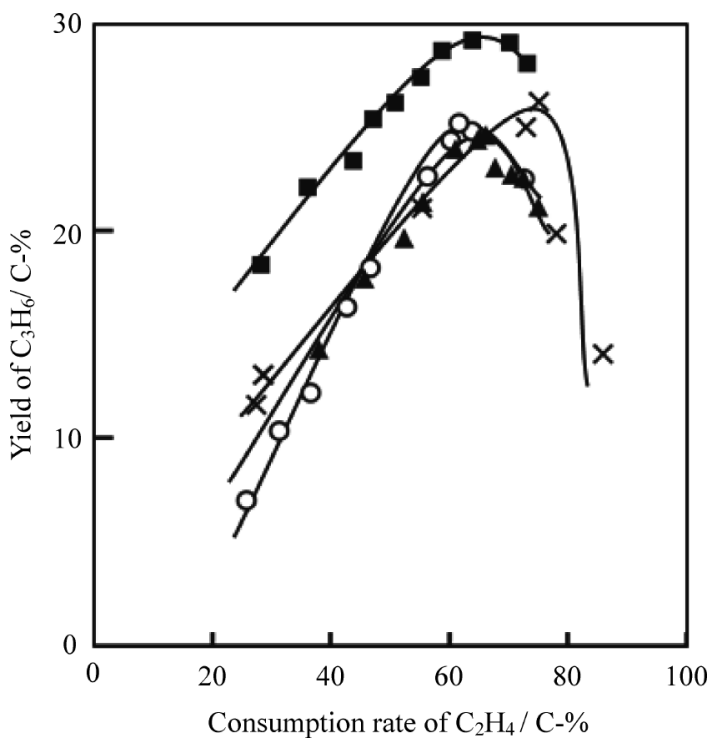

Temp. $=550{ }^{\circ} \mathrm{C}$. Yields of $\mathrm{C}_{2} \mathrm{H}_{4}$ and $\mathrm{C}_{3} \mathrm{H}_{6}$ are initial values after $0.5 \mathrm{~h}$ of time-on-stream.

Fig. 14 Relationship between Consumption Rate of Ethylene and Yield of Propylene over ( $\boldsymbol{\Delta}$ ) HTON, (O) Sr/HTON, $(\times)$ HZSM-5, (ם) Sr/HZSM-5

and reached maximum yield. There were no differences between HTON and Sr/HTON in maximum propylene yield and ethylene consumption rate associated with the maximum propylene yield. On the other hand, HZSM-5 and Sr/HZSM-5 showed a large difference in the ethylene consumption rate; $75.1 \mathrm{C}-\%$ for HZSM-5 and 64.0 C-\% for Sr/HZSM-5. The ethylene consumption rates of HTON and $\mathrm{Sr} / \mathrm{HTON}$ were consistent with that of $\mathrm{Sr} / \mathrm{HZSM}-5^{17)}$. These results 
strongly suggest that the chemical properties of the active sites of HTON and Sr/HTON are similar to that of $\mathrm{Sr} / \mathrm{HZSM}-5$, indicating the strontium cations in $\mathrm{Sr} /$ HZSM-5 are located at the intersections of the straight and sinusoidal channels and mainly catalyze the formation of propylene in the straight channels.

\section{Conclusions}

To clarify the potential of zeolites with straight channels for zeolitic ethanol conversion into light olefins, especially propylene, protonated TON type zeolites with different $\mathrm{SiO}_{2} / \mathrm{Al}_{2} \mathrm{O}_{3}$ ratios were synthesized and catalytic performances for conversion of ethanol were investigated. TON type zeolite has 10 -membered rings and only straight channels. The propylene yield strongly depended on both the $\mathrm{SiO}_{2} / \mathrm{Al}_{2} \mathrm{O}_{3}$ ratio and the $W / F$ value. The high propylene yield of $c a .25 \mathrm{C}-\%$ was achieved. These results indicate that HTON catalyst has high potential for the production of propylene from ethanol. The catalytic performance of HTON type zeolite was slightly improved by strontium modification.

\section{Acknowledgment}

This work was supported by a New Energy and Industrial Technology Development Organization (NEDO) grant.

\section{References}

1) Choudhary, V. R., Nayak, V. S., Zeolites, 5, 325 (1985)

2) Saha, S. K., Sivasanker, S., Catal. Lett., 15, 413 (1992).

3) Costa, E., Uguina, A., Aguado, J., Hernandez, P. J., Ind. Eng. Chem., Process. Des. Dev., 24, 239 (1985).

4) Talukdar, A. K., Bhattacharyya, K. G., Sivasanker, S., Appl. Catal. A: General, 148, 357 (1997).

5) Aguayo, A. T., Gayubo, A. G., Tarrío, A. M., Atutxa, A., Bilbao, J., J. Chem. Technol. Biotechnol., 77, 211 (2002).

6) Inaba, M., Murata, K., Saito, M., Takahara, I., React. Kinet. Catal. Lett., 88, 135 (2006)

7) Calsavara, V., Baesso, M. L., Fernandes-Machado, N. R. C.,
Fuel, 87, 1628 (2008)

8) Zhang, D., Wang, R., Yang, X., Catal. Lett., 124, 384 (2008).

9) Ferreira-Madeira, F., Gnep, N. S., Magnoux, P., Maury, S., Cadran, N., Appl. Catal. A: General, 367, 39 (2009).

10) Ouyang, J., Kong, F., Su, G., Hu, Y., Song, Q., Catal. Lett., 132, 64 (2009).

11) Oikawa, H., Shibata, Y., Inazu, K., Iwase, Y., Murai, K., Hyodo, S., Kobayashi, G., Baba, T., Appl. Catal. A: General, 312, 181 (2006).

12) Murata, K., Inaba, M., Takahara, I., J. Jpn. Petrol. Inst., 51, (4), 234 (2008).

13) Zhu, Q., Kondo, J. N., Inagaki, S., Tatsumi, T., Top. Catal., 52, 1272 (2009).

14) Yamazaki, T., Kikuchi, N., Katoh, M., Okada, Y., Yoshikawa, T., Wada, M., J. Jpn. Petrol. Inst., 52, (5), 239 (2009).

15) Song, Z., Takahashi, A., Mimura, N., Fujitani, T., Catal. Lett., 131, 364 (2009).

16) Inoue, K., Okabe, K., Inaba, M., Takahara, I., Murata, K., Reac. Kinet. Mech. Cat., 101, 477 (2010).

17) Goto, D., Harada, Y., Furumoto, Y., Takahashi, A., Fujitani, T., Oumi, Y., Sadakane, M., Sano, T., Appl. Catal. A: General, 383, 89 (2010).

18) le Febre, R. A., Kouwenhoveb, H. W., van Bekkum, H., Zeolites, 8, 60 (1988).

19) Martens, J. A., Souverijns, W., Verrelst, W., Parton, R., Froment, G. F., Jacobs, P. A., Angew. Chem., Int. Ed. Engl., 34, 2528 (1995).

20) Martens, J. A., Verrelst, W. H., Mathys, G. M., Brown, S. H., Jacobs, P. A., Angew. Chem., Int. Ed., 44, 5687 (2005).

21) Li, J., Wei, Y., Liu, G., Qi, Y., Tian, P., Li, B., He, Y., Liu, Z., Catal. Today, 171, 221 (2011).

22) Sano, T., Suzuki, A., Fukuya, S., Matsuoka, F., Wang, Z. B., Soga, K., Kohtoku, Y., "Proceeding of the 12th International Zeolite Conference," eds. by Treacy, M. M. J., Marcus, B. K., Bisher, M. E., Higgins, J. B., Materials Research Society, PA (1998), Vol. 3, p. 2041-2048.

23) Ernst, S., Weitkamp, J., Martens, J. A., Jacobs, P. A., Appl. Catal., 48, 137 (1989).

24) Brade, R. B., Adnot, A., Kaliaguine, S., Zeolites, 11, 710 (1991).

25) Hayasaka, K., Liang, D., Huybrechts, W., Waele, B. R. D., Houthoofd, K. J., Eloy, P., Gaigneaux, E. M., Tendeloo, G. V., Thybaut, J. W., Marin, G. B., Denayer, J. F. M., Baron, G. V., Jacobs, P. A., Kirschhock, C. E. A., Martens, J. A., Chem. Eur. J., 13, 10070 (2007).

26) Woolery, G. L., Alernany, L. B., Dessau, R. M., Chester, A. W., Zeolites, 6, 14 (1986). 
要旨

\section{TON 型ゼオライト上でのエタノール転化によるプロピレン合成}

津野地 直, 古本 祥康, 井出 裕介, 定金 正洋, 佐野 庸治

広島大学大学院工学研究科応用化学専攻, 739-8527 広島県東広島市鏡山1-4-1

\begin{abstract}
1,6-ジアミノヘキサン,$n$-ブチルアルコールおよび1-エチル ピリジニウムブロミドを構造規定剤に用いて $\mathrm{SiO}_{2} / \mathrm{Al}_{2} \mathrm{O}_{3}$ 比 57 , 81，112 掞よび 140 の TON 型ゼオライトを合成した。10員環 $(0.46 \mathrm{~nm} \times 0.57 \mathrm{~nm})$ のストレートチャンネルのみを有するゼ オライトである HTON 型ゼオライトの低級オレフィンへのエ タノール転化性能について検討した。低級オレフィン（エチ レン, プロピレン, ブテン）収率は用いた HTON 型ゼオライ トの $\mathrm{SiO}_{2} / \mathrm{Al}_{2} \mathrm{O}_{3}$ 比㧍よび反応条件（温度, 接触時間）に大きく
\end{abstract}

依存したが, プロピレン収率は約 25 C-\% と比較的高い值が得 られた。また, $\mathrm{SiO}_{2} / \mathrm{Al}_{2} \mathrm{O}_{3}$ 比の高い $\mathrm{HTON}$ 型ゼオライトほど比 較的安定した触媒性能を示した。これらの結果は, 10 員環の ストレートチャンネルのみを有する TON 型ゼオライトはエ夕 ノールからのプロピレン合成のための触媒として高いポテン シャルを有していることを示している。HTON 型ゼオライトの 触媒性能はストロンチウム修飾により若干向上した。 